\title{
Carbon footprint assessment for a local branded pure milk product: a lifecycle based approach
}

\author{
Rui ZHAO ${ }^{1 *}$, Yao XU², Xiangyu $\mathrm{WEN}^{1}$, Ning $\mathrm{ZHANG}^{3}$, Jiapei CAI ${ }^{1}$
}

\begin{abstract}
This paper provides a simplified life cycle based assessment for a local branded pure milk product, to measure its related carbon footprint, including production of raw milk, dairy processing, transportation of milk product and disposal of packaging waste. The results show that the total carbon footprint of the pure milk is $1120 \mathrm{~g} \mathrm{CO}_{2} / \mathrm{L}$. The production of raw milk is identified as the major contributor to the carbon footprint. This contribution has amounted to $843 \mathrm{~g}$ of $\mathrm{CO}_{2}$ per liter of pure milk, accounted for $75.27 \%$ of the total carbon footprint. The carbon footprint of product transportation is $38 \mathrm{~g}$ of $\mathrm{CO}_{2}$ per liter, which accounts for $3.39 \%$ of the total. The carbon footprint related to the dairy processing and disposal of waste packaging is $173 \mathrm{~g}$ of $\mathrm{CO}_{2}$ per liter and $66 \mathrm{~g}$ of $\mathrm{CO}_{2}$ per liter, accounting for $15.45 \%$ and $5.89 \%$ of the total, respectively. The carbon footprint assessment intends to help dairy enterprises identify the intensive sectors of carbon emissions, and provides insight into improvement of product environmental performances.
\end{abstract}

Keywords: pure milk; carbon footprint; life cycle; life cycle based assessment.

Practical Application: This study identifies the most carbon-intensive sector in the life cycle of a pure milk product in China.

\section{Introduction}

Global climate change has become a worldwide challenge, sourced by Greenhouse gas (GHG) emissions which poses risk to the living environment, health, and safety of human beings (Mantyka-Pringle et al., 2015). Agricultural production is an important source of GHG emissions, accounting for 15 to $25 \%$ of the total anthropogenic GHG emissions, of which dairy products constitute approximately 5\% (Laratte et al., 2014; Hawkins et al., 2015). China is the third world largest consumer of dairy products (Hagemann et al., 2012; Huang et al., 2014). The GHG emissions associated with dairy products are increasing annually, due to a continuous rise in consumer demand (Baek et al., 2014; Adler et al., 2015). With "green consumerism" gaining increasing influence on the market, development of low-carbon food is a practical need for the food industries to reduce their GHG emissions, as well as to pursue long-term commercial success (Beske et al., 2014; Biggs et al., 2015). Carbon footprint, is an effective indicator to embody the low-carbon concept, regarded as the total carbon emission of a certain product or service during its entire life cycle (Vergé et al., 2013; Dong et al., 2014).

A number of studies have conducted measuring the carbon footprint of dairy products, by using the life cycle assessment (LCA). For example, Cederberg \& Mattsson (2000) compared conventional production with organic production in terms of material, energy input, and environmental output, which showed that the organic milk had a smaller carbon footprint. The similar result was identified by Thomassen et al. (2008) and Flysjö et al. (2012), who identified that the organic milk production generated less GHG than the conventional production. Eide (2002) measured carbon emissions during entire life cycle of milk, including agricultural product input, milk production, transportation, and waste disposal. The results indicated that the agricultural product input was the largest contributor to the carbon footprint. Specifically, Hospido et al. (2003) found that the carbon footprint produced by feeding of dairy cows was the largest. On this basis, Rotz et al. (2010) employed LCA to identify that the feed level may have a significant impact on the milk carbon footprint. By using LCA to calculate the carbon footprints of 11 dairy products, Vergé et al. (2013) further pointed out varying climate and dairy herd management could also have an impact. González-García et al. (2013) used LCA to measure the carbon footprint of yogurt, and found that carbon footprints in raw milk production and processing were the largest. O'Brien et al. (2014) employed LCA to compare carbon footprint of dairy products from high-performing confinement and grass-based dairy farms in the United States and the United Kingdom. They further incorporated the economic performances of dairy farms into the calculation of the carbon footprint, in order to achieve an outcome that was mutually beneficial for the economy and the environment (O'Brien et al., 2015).

The previous studies are useful in informing our approach. However, the conventional LCA, due to its complexities in required data acquistion, system boundary division etc., is difficult for engineers to implement in real applications (Chen \& Corson, 2014). This study is expected to provide a simplified assessment 
approach based upon a LCA framework of milk, mainly focuses on presenting its carbon emissions information to consumers, to help local dairy enterprises identify the most carbon-intensive sector of the whole life cycle, especially encourage the dairy enterprises with a higher environmental morality to have a product carbon labelling attempt, thus to provide effective measures for emissions reduction in dairy supply chain.

\section{Material and methods}

LCA is to assess possible environmental impact based upon the quantitative survey of a product during its whole life cycle, by identifying environmental emissions of all materials and energy, to seek opportunities on improvement of product environmental performances (Huysveld et al., 2015). As defined by International Organization for Standardization (ISO), a precise LCA generally follows by four phases: Goal and scope definition, Life cycle inventory analysis (LCI), Life cycle impact assessment (LCIA), and Interpretation (AzariJafari et al., 2016). Compared with the conventional LCA, the process of life cycle impact assessment is simplified in this study, as it mainly uses different categories of indicators to elaborate results of life cycle inventory (Nigri et al., 2014). However, only the product carbon footprint is considered in the impact category as the global warming potential, represented by $\mathrm{kg} \mathrm{CO} 2 \mathrm{e}$ per $\mathrm{kg}$ emission. Other impacts, such as eutrophication, acid rain potential, toxicity etc., have been omitted in this study. As a lifecycle study may not always need to use impact assessment, the results of the LCI provide information of a product system, including all inputs and outputs in the form of elementary flows (Seppälä, 2003), which is used to quantify the impact of carbon emissions in this study.

The Tetra Pak 1litre pure liquid milk is selected to assess its lifecycle based carbon footprint. System boundary is a key component of LCA, which directly affects the assessment precision (Park et al., 2016). This study only focused on processes that directly contributed to pure milk production, that is, only the effects of energy and material input and carbon emissions, as shown in Figure 1. The system boundary of milk life cycle is thus simplified and divided into four stages, namely, raw milk production, dairy product processing, product transportation and packaging waste disposal.

The carbon footprint is comprised of two parts, namely, direct GHG emissions and indirect GHG emissions, as shown in Equation 1 (IPCC, 2006):

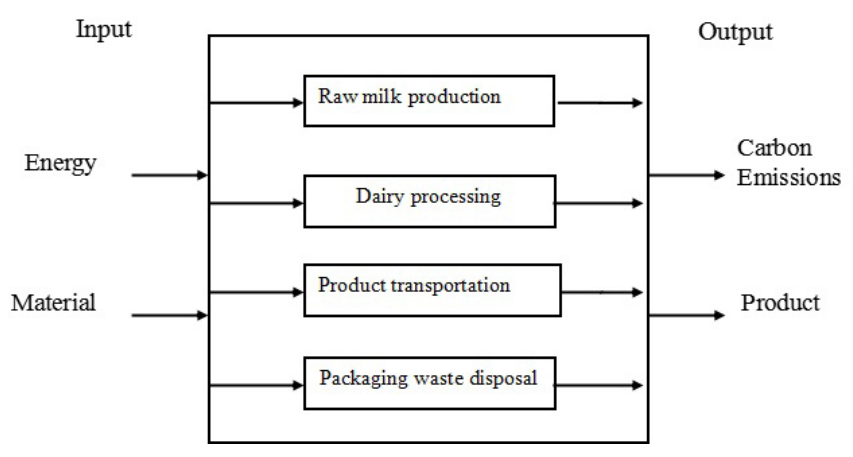

Figure 1. System boundary of a pure milk product.
$G H G_{\text {total }}=G H G_{\text {direct }}+G H G_{\text {indirect }}$

The direct emissions could be obtained by monitoring chemometrics, mass balance, or similar methods, and are calculated by using the following Equation 2 (IPCC, 2006):

$G H G_{\text {direct }}=\sum_{i=1}^{n} D_{i} \times G W P_{i}$

where i refers to the ith emissions source of milk life cycle, D the activity level, GWP the global warming potential.

The indirect emissions are calculated by using the following Equation 3 (IPCC, 2006):

$G H G_{\text {indirect }}=\sum_{i=1}^{n} A_{i} \times E_{i}$

where i refers to the ith emissions source of milk life cycle, A the activity level, which involves the amount of all resource and energy during the product life cycle (material input and output, energy use, transportation distance, etc.) $\mathrm{E}$ is the GHG emission factor, which refers to the GHG produced per unit activity level, derived from life cycle databases and industrial reports.

\subsection{Case background}

The milk source base is located at Hongya Country, Southwestern Sichuan Province, China, about 147 kilometres far from Chengdu City, the provincial capital. The diary processing plant is located at Pixian, suburb of Chengdu City, which is about 175 kilometres far from the milk source base. The branded milk is mainly distributed to the central Chengdu City, about 40 kilometres distances from the diary processing plant. The milk packaging waste is transported to the municipal landfill for final disposal, about 30 kilometres away from the central city. The detailed geographic distribution of the milk supply chain network is shown in Figure 2.

\subsection{Source of inventory data}

Table 1 shows the inventory data during the raw milk production stage, which are obtained by analogy to Hospido et al. (2003) on milk LCA. The location of the raw milk production is dairy farms, where the main consumptions are fodder, electricity, and diesel. From a conversion of the results obtained by Hospido et al. (2003) on GHG emissions factors from farm fodder and equipment disinfectant, a corresponding $\mathrm{CO}_{2}$ emission coefficient is obtained for the calculation. The electricity emission factor is based on the 2014 Baseline Emission Factors for Regional Power Grids in China, released by National Development and Reform Commission, of which the Central China power-grid emission factor is used in this study. The operating margin emissions factor is $0.972 \mathrm{t} \mathrm{CO}_{2} / \mathrm{MWh}$, and the build margin emissions factor is $0.47 \mathrm{t} \mathrm{CO} / \mathrm{MWh}$ (NDRC, 2014). Through the conversion, the power grid emission factor is $0.723 \mathrm{~kg} / \mathrm{kW} \cdot \mathrm{h}$.

Table 2 shows the inventory data of the dairy processing stage. Specifically, a large amount of water is needed during the cooling and pre-heating of raw milk, as well as the pre-heating 


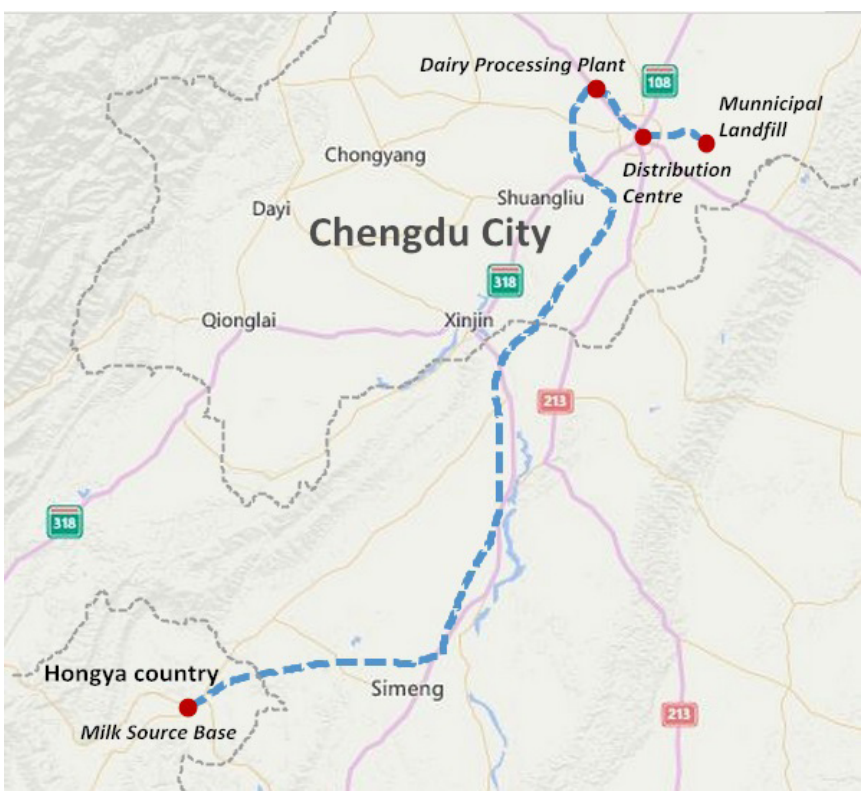

Figure 2. The geographic distribution of the local branded milk supply chain. and sterilization of the liquid milk. Electricity is mainly used for operating the equipment, and fuels are used to generate the steam required for the pre-heating and heating of the sterilizer (Riera et al., 2013). Cardboard paper is used to produce the outer packaging for the milk.

The carbon footprint of product transportation is calculated by transportation loads (tonne. $\mathrm{km}$ ) multiplying the carbon emissions factor (Cai et al., 2012). According to the field investigation, light-weight gasoline truck in 2 tonnes of loading capacity is employed to transport the raw milk from the pasture to the processing plant, then to the distribution centre, and their distances are 175 kilometres and 40 kilometres, respectively. Heavy-weight disel truck in 10 tonnes of loading capacity is employed to transport the packaging waste to the municipal landfill, with a distance of 30 kilometres. The carbon emissions factors of gasoline and diesel are measured by IPCC (2006), as $164 \mathrm{~g}$ per tonne kilometer for 2 tonnes light-weight gasoline truck, 84.8 g per tonne kilometer for 10 tonnes Heavy-weight disel truck, respectively, as shown in Table 3.

Recycling is selected for the packaging waste pre-treatment. Because of the separation technique for aluminum-plastic

Table 1. Inventory data of the raw milk production.

\begin{tabular}{cccccc}
\hline \multirow{2}{*}{ Emissions type } & Emissions source & Activity level & CO $_{2}$ emissions factor & $\begin{array}{c}\text { Source of emissions } \\
\text { factor }\end{array}$ & Carbon footprint (g) \\
\hline \multirow{2}{*}{ Energy } & Electricity & $0.047 \mathrm{~kW} \cdot \mathrm{h}$ & $0.723 \mathrm{~kg} / \mathrm{kW} \cdot \mathrm{h}$ & NDRC $(2014)$ & 34 \\
& Diesel & $3.68 \mathrm{ml}$ & $2.73 \mathrm{~g} / \mathrm{ml}$ & IPCC $(2006)$ & 10 \\
\hline \multirow{3}{*}{ Material } & Fodder & $1290 \mathrm{~g}$ & $0.403 \mathrm{~g} / \mathrm{g}$ & Hospido et al. $(2003)$ & 522 \\
& Disinfectant & $1.59 \mathrm{ml}$ & $1.79 \mathrm{~g} / \mathrm{ml}$ & Hospido et al. (2003) & 2.85 \\
& Water & $2.66 \mathrm{~L}$ & $0.009 \mathrm{~g} / \mathrm{L}$ & Field investigation & 0.25 \\
\hline
\end{tabular}

Table 2. Inventory data of the dairy processing.

\begin{tabular}{cccccc}
\hline Emissions type & Emissions sources & Activity level & $\mathrm{CO}_{2}$ emissions factor & $\begin{array}{c}\text { Source of emissions } \\
\text { factor }\end{array}$ & Carbon footprint (g) \\
\hline \multirow{2}{*}{ Energy } & Diesel & $7.07 \mathrm{~g}$ & $2.73 \mathrm{~g} / \mathrm{ml}$ & IPCC $(2006)$ & 22.8 \\
& Electricity & $0.047 \mathrm{~kW} \cdot \mathrm{h}$ & $0.723 \mathrm{~kg} / \mathrm{kW} \cdot \mathrm{h}$ & NDRC $(2014)$ & 33.5 \\
\hline \multirow{5}{*}{ Material } & Cardboard paper & $16.8 \mathrm{~g}$ & $1.04 \mathrm{~g} / \mathrm{g}$ & DEFRA (2012) & 17.4 \\
& Membrane & $0.183 \mathrm{~g}$ & $2.85 \mathrm{~g} / \mathrm{g}$ & WRI (2004) & 0.522 \\
& Equipment cleaning & $2.91 \mathrm{~g}$ & $0.649 \mathrm{~g} / \mathrm{g}$ & Field investigation & 1.89 \\
& Tetra Pak & $1.01 \mathrm{U}$ & $0.952 \mathrm{~g} / \mathrm{U}$ & Field investigation & 96.1 \\
& Water & $4.41 \mathrm{~L}$ & $0.094 \mathrm{~g} / \mathrm{L}$ & Field investigation & 0.415 \\
\hline
\end{tabular}

Table 3. Inventory data of the product transportation.

\begin{tabular}{|c|c|c|c|c|}
\hline Transportation sub-stages & Activity level $(\mathrm{t} \cdot \mathrm{km})$ & $\begin{array}{c}\mathrm{CO}_{2} \text { emissions factor } \\
(\mathrm{g} / \mathrm{t} \cdot \mathrm{km})\end{array}$ & Source of emissions factor & Carbon footprint (g) \\
\hline Raw milk transportation & 0.175 & 164 & $\begin{array}{c}\text { IPCC (2006) } \\
\text { Cai et al. (2012) }\end{array}$ & 28.7 \\
\hline Milk distribution & 0.04 & 164 & $\begin{array}{c}\text { IPCC (2006) } \\
\text { Cai et al. (2012) }\end{array}$ & 6.55 \\
\hline $\begin{array}{l}\text { Packaging waste } \\
\text { Transportation }\end{array}$ & 0.03 & 84.8 & $\begin{array}{c}\text { IPCC (2006) } \\
\text { Cai et al. (2012) }\end{array}$ & 2.54 \\
\hline
\end{tabular}


composites usually with a lower heating value, these containers are not suitable for incineration (Xie et al., 2011). Therefore, landfill disposal is the ultimate choice (Meneses et al., 2012). Data on the carbon emissions during the landfill stage are by analogy to Cherubini's inventory of sanitary landfill disposal (Cherubini et al., 2009), shown in Table 4.

\section{Results and discussion}

The carbon footprints related to the four stages are listed in Table 5. The results show that for a typical 1L Tetra Pak of pure milk, the carbon footprint for its whole life cycle is $1120 \mathrm{~g}$, of which $843 \mathrm{~g}$ is generated during the raw milk production, accounting for $75.27 \%$ of the total carbon footprint. The second stage is that of dairy processing, for which the carbon footprint is $173 \mathrm{~g}$, accounting for $15.45 \%$. The third stage of product transportation contributes $38 \mathrm{~g}$ of the carbon footprint, accounting for $3.39 \%$. The carbon footprint in the stage of packaging waste disposal is $66 \mathrm{~g}$, accounting for $5.89 \%$.

\subsection{Carbon footprint of the raw milk production}

The carbon footprint of the raw milk production is $843 \mathrm{~g}$, which is identified as the major source of the carbon footprint in the milk lifecycle. Specifically, farm fodder, such as corn and silage are the largest contributors (522g), accounting for $46.61 \%$ of the total carbon footprint. The methane emissions of dairy cows are the second highest, with a carbon footprint of $273 \mathrm{~g}$, accounting for $24.38 \%$ of the total carbon footprint, as shown in Figure 3. This may be attributable to the ruminant digestive system of dairy cows, thus may give rise to a large amount of methane (Wang et al., 2016).

\subsection{Carbon footprint of the dairy processing}

In the dairy processing stage, the carbon footprint is $173 \mathrm{~g}$, accounting for $15.45 \%$ of the total. Figure 4 shows that the major emissions source is the Tetra Pak production, which has a carbon footprint of $96 \mathrm{~g}$, accounting for $8.58 \%$ of the total. Electricity and diesel energy consumption contribute $34 \mathrm{~g}$ and $23 \mathrm{~g}$ of carbon footprint, respectively, which account for $2.99 \%$ and $2.04 \%$ of the total. The carbon footprint of cardboard production is $18 \mathrm{~g}$, accounting for $1.56 \%$ of the total. The carbon footprint contributions of water and membranes are relatively low (both $<0.1 \%$ ).

\subsection{Carbon footprint of the product transportation}

The product transportation is consisted by three sub-stages, as raw milk transportation, milk distribution and packaging waste transportation. Raw milk transportation has a carbon footprint of $29 \mathrm{~g}$, accounting for $75.91 \%$ of the carbon footprint at this stage. Milk distribution and transportation of packaging disposal contribute $7 \mathrm{~g}$ and $3 \mathrm{~g}$ of carbon footprint respectively, which account for $17.35 \%$ and $6.74 \%$ of the carbon footprint at this stage, as shown in Figure 5.

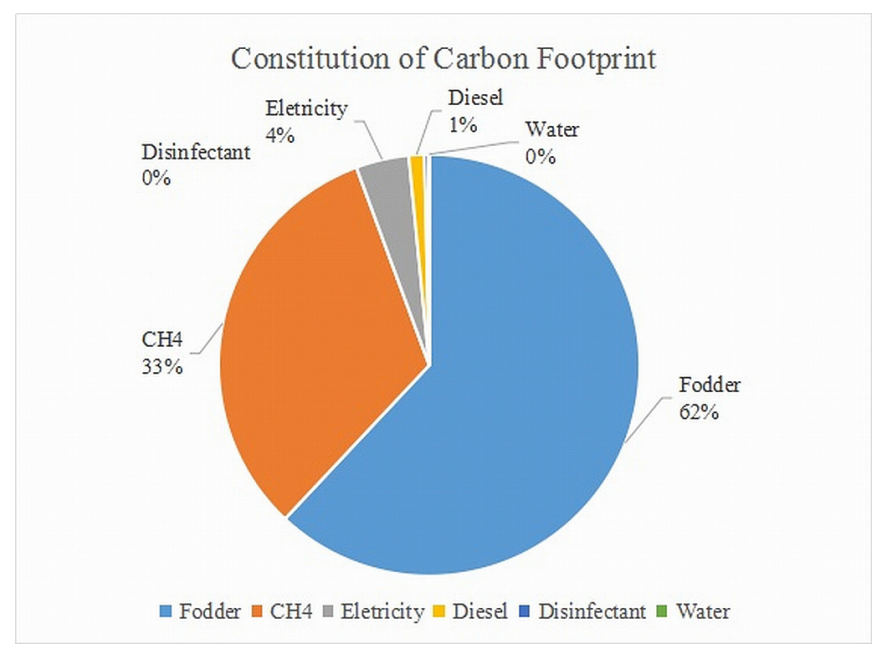

Figure 3. Carbon footprint of the raw milk production.

Table 4. Inventory data of the packaging waste disposal.

\begin{tabular}{|c|c|c|c|c|c|c|}
\hline \multicolumn{2}{|c|}{ Emissions type } & Emissions source & Activity level & $\begin{array}{l}\mathrm{CO}_{2} \text { emissions } \\
\text { factor }\end{array}$ & $\begin{array}{l}\text { Source of emissions } \\
\text { factor }\end{array}$ & Carbon footprint (g) \\
\hline \multirow{6}{*}{ Recycling } & \multirow{4}{*}{ Energy } & Raw coal & $9.03 \mathrm{~g}$ & $2.69 \mathrm{~g} / \mathrm{g}$ & IPCC (2006) & 24.3 \\
\hline & & Natural gas & $4.63 \times 10^{-10} \mathrm{~m}^{3}$ & $2.09 \mathrm{~kg} / \mathrm{m}^{3}$ & IPCC (2006) & $9.68 \times 10^{-10}$ \\
\hline & & Crude oil & $0.00776 \mathrm{~g}$ & $3.07 \mathrm{~g} / \mathrm{g}$ & IPCC (2006) & 0.0238 \\
\hline & & Electricity & $0.0114 \mathrm{~kW} \cdot \mathrm{h}$ & $723 \mathrm{~g} / \mathrm{kW} \cdot \mathrm{h}$ & NDRC (2014) & 8.24 \\
\hline & & $\mathrm{CO}_{2}$ & $15.5 \mathrm{~g}$ & $1.00 \mathrm{~g} / \mathrm{g}$ & DEFRA (2012) & 15.5 \\
\hline & & $\mathrm{CH}_{4}$ & $0.0843 \mathrm{~g}$ & $25 \mathrm{~g} / \mathrm{g}$ & DEFRA (2012) & 2.11 \\
\hline \multicolumn{2}{|c|}{ Landfill disposal } & & $12 \mathrm{~g}$ & $1.31 \mathrm{~g} / \mathrm{g}$ & Cherubini et al. (2009) & 15.7 \\
\hline
\end{tabular}

Table 5. Carbon footprint of different lifecycle stages.

\begin{tabular}{ccc}
\hline Emission types & Carbon footprint $\left(\mathrm{g} \mathrm{CO}_{2}\right.$ per litre $)$ & Percentage $(\%)$ \\
\hline Raw milk production & 843 & 75.27 \\
Dairy processing & 173 & 15.45 \\
Product transportation & 38 & 3.39 \\
Packaging disposal & 66 & 5.89 \\
Total & 1120 & 100 \\
\hline
\end{tabular}




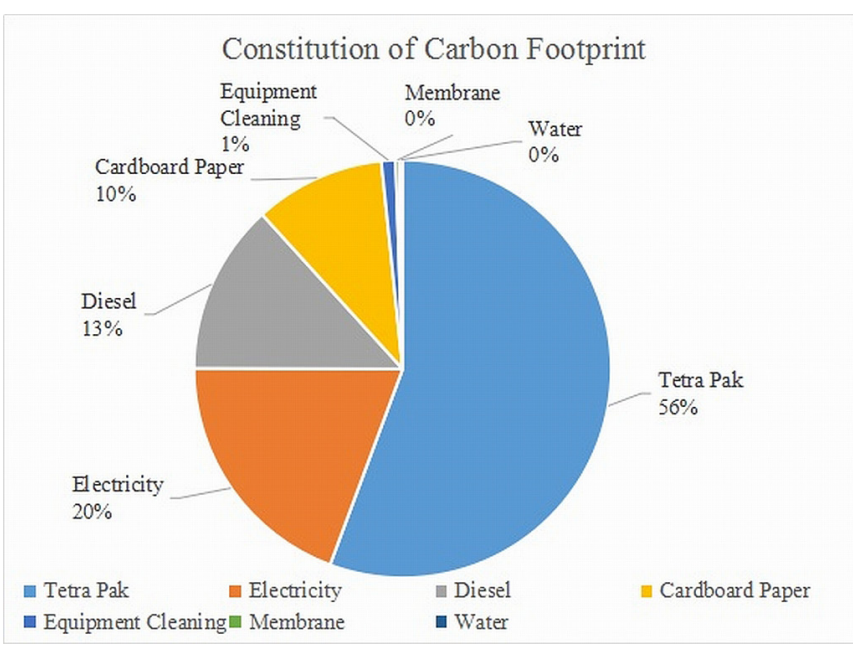

Figure 4. Carbon footprint of the dairy processing.

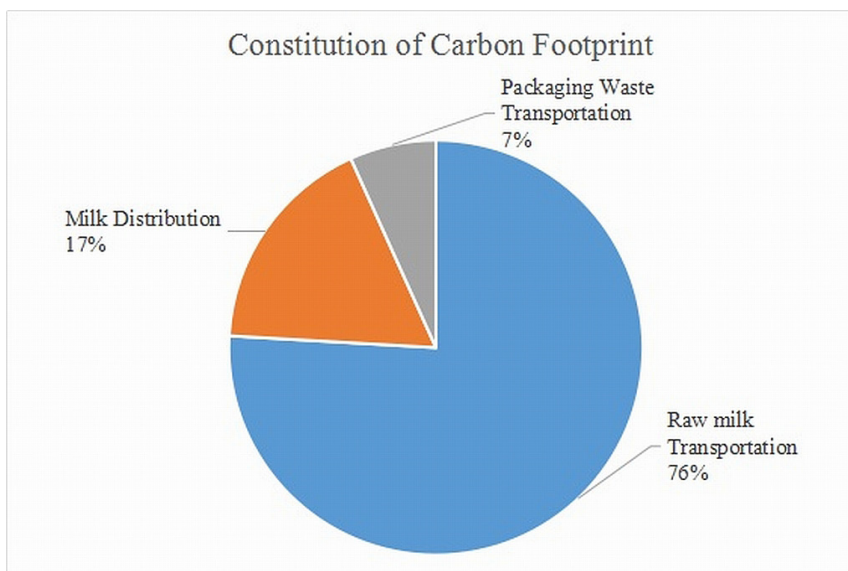

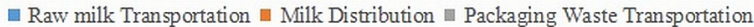

Figure 5. Carbon footprint of the product transportation.

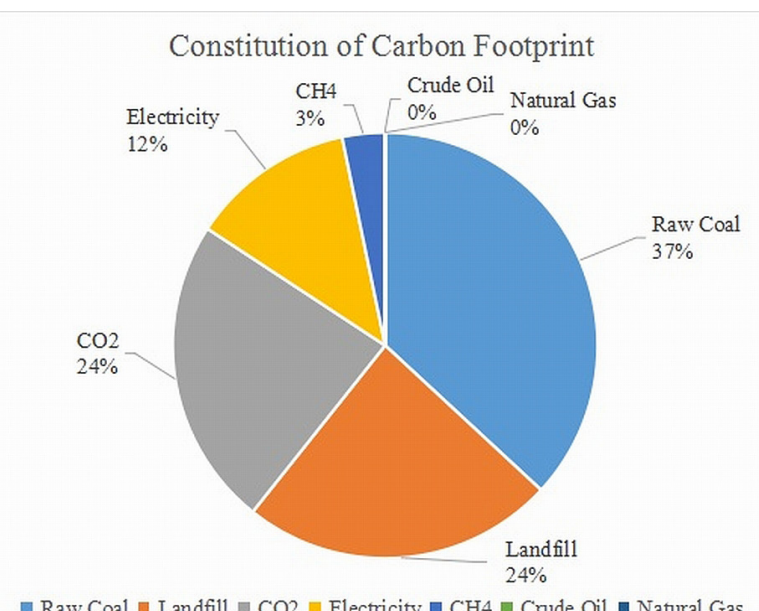

Figure 6. Carbon footprint of the packaging waste disposal.

\subsection{Carbon footprint of the packaging waste disposal}

At the packaging waste disposal stage, the carbon footprint is $66 \mathrm{~g}$, accounting for $5.89 \%$ of the total. Figure 6 indicates that the major emissions source is raw coal consumption, which has a carbon footprint of $24 \mathrm{~g}$, accounting for $36.87 \%$ of the carbon footprint at this stage. Landfill disposal is the second highest, which has a carbon footprint of $16 \mathrm{~g}$, accounting for $23.82 \%$ of carbon emission at this stage. The carbon footprint associated with direct $\mathrm{CO}_{2}$ and $\mathrm{CH}_{4}$ emissions are $15 \mathrm{~g}$ and $2 \mathrm{~g}$, which account for $23.52 \%$ and $3.2 \%$ of carbon emissions at this stage, respectively. Electricity consumption contributes $8.24 \mathrm{~g}$ of carbon footprint, which is $12.50 \%$ of the carbon footprint at this stage. As the consumption of crude oil and natural gases is relatively low, the contributions to the carbon footprint account for less than $0.05 \%$.

\subsection{Discussion}

The carbon footprint refers to the total carbon emissions of a certain product or service during its entire life cycle, directly or indirectly emitted by agents (individuals, organizations, or departments) during a certain activity (Zhao et al., 2012). LCA aims to help enterprises and organizations in assessment of environmental impact of whole supply chain of a product, identify most intensive emissions sector, thus to propose effective measures for emissions reduction, and optimize resource distribution and utilization (Kulak et al., 2016). However, many uncertainties still remain in product carbon footprint assessment, e.g., various assessment standards may give rise to different results (Liu et al., 2016). For the simplified approach, the specific uncertainties regarding to the assessment results are: (1) different division of system boundaries may lead to deviation in carbon footprint assessment. The system boundary of the study has been strictly defined, which only contains four procedures related to the pure milk product, i.e., raw milk production, dairy processing, product transportation and packaging waste disposal. However, the upper stream of the raw milk production, e.g., the raw milk source, as well as the downstream of product transportation, e.g., the product use, has been deliberately omitted from the system boundary. (2) the simplified approach mainly focuses on the inventory analysis for the impact assessment, which is quantified by the activity level multiplying the emissions factor. With regard to the activity level, it is closely related to the data acquaintance. However, there may be difficulties in obtaining the required data, thus limits the precision of calculated values. Emissions factor is another critical input for the impact assessment. Although some of the emissions factors have been measured by the field investigation, a number of factors, such as energy sources (electricity, diesels), fodder, disinfectant etc., are derived from the similar studies. Thus, there may be biases in the assessment results.

The results indicate that the largest contributor to the carbon footprint occurred at the acquisition stage of the raw milk, which accounts for $93.90 \%$ of the total carbon footprint. The results are consistent with those of the study by González-García et al. (2013), which has indicated that raw milk production generated the highest carbon footprint (80 to 90\%) in the yogurt life cycle. Raw milk is considered taking from conventional dairy farming 
in the study, through which the carbon footprint at this stage accounts for $75.27 \%$ of the total. In the study by Hospido et al. (2003), the carbon footprint of the subsystem related to breeding during the farming stage accounts for $80.32 \%$ of the total carbon footprint, which is similar to the results of our study. Fodder has an impact on the GHG emissions related to dairy cows, and especially the ratio of the ingredients in the mixed animal fodder has a significant influence (Castanheira et al., 2010). Based upon our field investigation, dairy cows are fed large amounts of coarse fodder due to its low cost. However, digesting this type of fodder may increase $\mathrm{CH}_{4}$ emissions (Muñoz et al., 2015; Hatew et al., 2016). Adjustment of the ratio of corn and coarse fodder in the animal feed may contribute to limiting the amounts of GHG being emitted (Van-Middelaar et al., 2013). In addition, Excessive nitrogen fertilizer has been applied in the agricultural sector of China for a long time (Ha et al., 2015). The fertilizer in the soil would release $\mathrm{N}_{2} \mathrm{O}$ by denitrification and in this way increase GHG emissions (Rowlings et al., 2013). Thus, to create an effective balance between nutritional value and environmental impact is significant to be considered in fodder ingredients (Dutreuil et al., 2014).

The packaging-waste disposal contributes $5.89 \%$ to the total carbon footprint. In China, landfilling is mostly used to dispose of paper-aluminum-plastic composite packaging. However, it may cause the generation of harmful non-degradable substances (Woon \& Lo, 2013).To increase the recycling ratio may significantly mitigate the adverse environmental impact of the packaging waste disposal, in which development of aluminum-plastic separation technology is effective.

Currently, the implementation of carbon footprinting is voluntary for enterprises, who may consider assuming additional social responsibilities to improve the 'green performance' of their products (Noronha et al., 2013). However, additional cost for such a holistic carbon footprint assessment may give rise to uncertainty regarding commercial success (Zhao et al., 2013). For this reason, government should assume a leading role on the path to sustainability, e.g., motivates green innovation among enterprises through well designed policy instruments, to help enterprises achieve a 'win-win' performance between the environment and the economy (Zhao et al., 2016). Governmental policy instruments can be divided into the incentive and punitive mechanism, in which the former contains subsidy, tax preference, price regulation etc. to decrease financial risk in green transition, whilst the latter mainly focuses on compulsive measure, i.e., economic sanction, to drive product innovation (Zhao et al., 2017). In addition, the external force from consumers is also a decisive factor to drive the enterprises to have the carbon footprinting attempt. With consumers' environmental awareness being gradually increased, their purchasing intention and willingness to pay may be influenced by a product carbon label, i.e., a tag summary to present the information of carbon footprint throughout a product lifecycle (Zhao et al., 2012; Aung \& Chang, 2014). For instance, recent investigation shows that $50 \%$ of consumers in UK have chosen at least one carbon-labeled item while shopping in Tesco (Zhao et al., 2012). This would provide such business opportunities for enterprises to benefit from the sale of carbon labelled products, thus to cover the additional cost of carbon footprint assessment.

\section{Conclusions}

A simplified life cycle based assessment is employed to calculate the carbon footprint of a pure milk product, which is based upon the inventory analysis. The result indicates that the carbon footprint mainly relates to the production of raw milk at the farm, contributing $75.27 \%$ to the emissions, whereas dairy processing, product transportation and disposing of the packaging waste contribute $15.45 \%, 3.39 \%$ and $5.89 \%$, respectively. As regards the raw milk production, carbon footprint may be reduced by adjusting the proportions of the animal fodder, thereby contributing to a reduction of the total carbon footprint. It is expected that this study may give insight to provide a transparent carbon emissions information to consumers, to encourage the dairy enterprises to implement emissions reduction related activities, thus to promote a low-carbon dairy industry. Further studies will focus on the improvement of the assessment, including the quality of data sources, sensitivity analysis etc., in order to measure the carbon footprint of milk products more precisely.

\section{Acknowledgements}

This study is sponsored by National Natural Science Foundation of China (No. 41301639; No. 41571520), Sichuan Provincial Key Technology Support (No. 2014GZ0168), and The Fundamental Research Funds for the Central Universities (No. A0920502051619).

\section{References}

Adler, A. A., Doole, G. J., Romera, A. J., \& Beukes, P. C. (2015). Managing greenhouse gas emissions in two major dairy regions of New Zealand: a system-level evaluation. Agricultural Systems, 135, 1-9. http://dx.doi.org/10.1016/j.agsy.2014.11.007.

Aung, M. M., \& Chang, Y. S. (2014). Traceability in a food supply chain: safety and quality perspectives. Food Control, 39, 172-184. http:// dx.doi.org/10.1016/j.foodcont.2013.11.007.

AzariJafari, H., Yahia, A., \& Ben Amor, M. (2016). Life cycle assessment of pavements: reviewing research challenges and opportunities. Journal of Cleaner Production, 112, 2187-2197. http://dx.doi.org/10.1016/j. jclepro.2015.09.080.

Baek, C. Y., Lee, K. M., \& Park, K. H. (2014). Quantification and control of the greenhouse gas emissions from a dairy cow system. Journal of Cleaner Production, 70, 50-60. http://dx.doi.org/10.1016/j. jclepro.2014.02.010.

Beske, P., Land, A., \& Seuring, S. (2014). Sustainable supply chain management practices and dynamic capabilities in the food industry: a critical analysis of the literature. International Journal of Production Economics, 152, 131-143. http://dx.doi.org/10.1016/j.ijpe.2013.12.026.

Biggs, E. M., Bruce, E., Boruff, B., Duncan, J. M. A., Horsley, J., Pauli, N., McNeill, K., Neef, A., Van Ogtrop, F. V., Curnow, J., Haworth, B., Duce, S., \& Imanari, Y. (2015). Sustainable development and the waterenergy-food nexus: a perspective on livelihoods. Environmental Science \& Policy, 54, 389-397. http://dx.doi.org/10.1016/j.envsci.2015.08.002.

O’Brien, D., Capper, J. L., Garnsworthy, P. C., Grainger, C., \& Shalloo, L. (2014). A case study of the carbon footprint of milk from highperforming confinement and grass-based dairy farms. Journal of Dairy Science, 97(3), 1835-1851. PMid:24440256. http://dx.doi. org/10.3168/jds.2013-7174. 
O’Brien, D., Hennessy, T., Moran, B., \& Shalloo, L. (2015). Relating the carbon footprint of milk from Irish dairy farms to economic performance. Journal of Dairy Science, 98(10), 7394-7407. PMid:26254524. http:// dx.doi.org/10.3168/jds.2014-9222.

Cai, B. F., Feng, X. Z., \& Chen, X. M. (2012). Transport carbon dixiode emissions and low carbon development (In Chinese) Beijing: Chemical Industry Press.

Castanheira, É. G., Dias, A. C., Arroja, L., \& Amaro, R. (2010). The environmental performance of milk production on a typical Portuguese dairy farm. Agricultural Systems, 103(7), 498-507. http:// dx.doi.org/10.1016/j.agsy.2010.05.004.

Cederberg, C., \& Mattsson, B. (2000). Life cycle assessment of milk production-a comparison of conventional and organic farming. Journal of Cleaner Production, 8(1), 49-60. http://dx.doi.org/10.1016/ S0959-6526(99)00311-X.

Chen, X., \& Corson, M. S. (2014). Influence of emission-factor uncertainty and farm-characteristic variability in LCA estimates of environmental impacts of French dairy farms. Journal of Cleaner Production, 81, 150-157. http://dx.doi.org/10.1016/j.jclepro.2014.06.046.

Cherubini, F., Bargigli, S., \& Ulgiati, S. (2009). Life cycle assessment (LCA) of waste management strategies: landfilling, sorting plant and incineration. Energy, 34(12), 2116-2123. http://dx.doi.org/10.1016/j. energy.2008.08.023.

Department of Environment Food and Rural Affairs - DEFRA. (2012). Guidelines to Defra/DECC's GHG conversion factors for company reporting. London: DEFRA. Retrieved from https://www.gov.uk/ government/publications/2012-guidelines-to-defra-decc-s-ghgconversion-factors-for-company-reporting-methodology-paperfor-emission-factors

Dong, Y., Xia, B., \& Chen, W. (2014). Carbon footprint of urban areas: an analysis based on emission sources account model. Environmental Science \& Policy, 44, 181-189. http://dx.doi.org/10.1016/j.envsci.2014.07.013.

Dutreuil, M., Wattiaux, M., Hardie, C. A., \& Cabrera, V. E. (2014). Feeding strategies and manure management for cost-effective mitigation of greenhouse gas emissions from dairy farms in Wisconsin. Journal of Dairy Science, 97(9), 5904-5917. PMid:24996278. http://dx.doi. org/10.3168/jds.2014-8082.

Eide, M. H. (2002). Life cycle assessment (LCA) of industrial milk production. The International Journal of Life Cycle Assessment, 7(2), 115-126. http://dx.doi.org/10.1007/BF02978855.

Flysjö, A., Cederberg, C., Henriksson, M., \& Ledgard, S. (2012). The interaction between milk and beef production and emissions from land use change-critical considerations in life cycle assessment and carbon footprint studies of milk. Journal of Cleaner Production, 28, 134-142. http://dx.doi.org/10.1016/j.jclepro.2011.11.046.

González-García, S., Castanheira, É. G., Dias, A. C., \& Arroja, L. (2013). Environmental life cycle assessment of a dairy product: the yoghurt. The International Journal of Life Cycle Assessment, 18(4), 796-811. http://dx.doi.org/10.1007/s11367-012-0522-8.

Ha, N., Feike, T., Back, H., Xiao, H., \& Bahrs, E. (2015). The effect of simple nitrogen fertilizer recommendation strategies on product carbon footprint and gross margin of wheat and maize production in the North China Plain. Journal of Environmental Management, 163, 146-154. PMid:26311087. http://dx.doi.org/10.1016/j. jenvman.2015.08.014.

Hagemann, M., Ndambi, A., Hemme, T., \& Latacz-Lohmann, U. (2012). Contribution of milk production to global greenhouse gas emissions. Environmental Science and Pollution Research International, 19(2), 390402. PMid:21792583. http://dx.doi.org/10.1007/s11356-011-0571-8.
Hatew, B., Bannink, A., Van Laar, H., De Jonge, L. H., \& Dijkstra, J. (2016). Increasing harvest maturity of whole-plant corn silage reduces methane emission of lactating dairy cows. Journal of Dairy Science, 99(1), 354-368. PMid:26506541. http://dx.doi.org/10.3168/ jds.2015-10047.

Hawkins, J., Weersink, A., Wagner-Riddle, C., \& Fox, G. (2015). Optimizing ration formulation as a strategy for greenhouse gas mitigation in intensive dairy production systems. Agricultural Systems, 137, 1-11. http://dx.doi.org/10.1016/j.agsy.2015.03.007.

Hospido, A., Moreira, M. T., \& Feijoo, G. (2003). Simplified life cycle assessment of Galician milk production. International Dairy Journal, 13(10), 783-796. http://dx.doi.org/10.1016/S0958-6946(03)00100-6.

Huang, J., Xu, C. C., Ridoutt, B. G., Liu, J. J., Zhang, H. L., Chen, F., \& Li, Y. (2014). Water availability footprint of milk and milk products from large-scale dairy production systems in Northeast China. Journal of Cleaner Production, 79, 91-97. http://dx.doi.org/10.1016/j. jclepro.2014.05.043.

Huysveld, S., Van linden, V., De Meester, S., Peiren, N., Muylle, H., Lauwers, L., \& Dewulf, J. (2015). Resource use assessment of an agricultural system from a life cycle perspective- a dairy farm as case study. Agricultural Systems, 135, 77-89. http://dx.doi.org/10.1016/j. agsy.2014.12.008.

Intergovernmental Panel on Climate Change - IPCC. (2006). Guidelines for national greenhouse gas inventories. Geneva. Retrieved from http://www.ipcc-nggip.iges.or.jp/public/2006gl/

Kulak, M., Nemecek, T., Frossard, E., \& Gaillard, G. (2016). Eco-efficiency improvement by using integrative design and life cycle assessment: the case study of alternative bread supply chains in France. Journal of Cleaner Production, 112, 2452-2461. http://dx.doi.org/10.1016/j. jclepro.2015.11.002.

Laratte, B., Guillaume, B., Kim, J., \& Birregah, B. (2014). Modeling cumulative effects in life cycle assessment: the case of fertilizer in wheat production contributing to the global warming potential. The Science of the Total Environment, 481, 588-595. PMid:24631622. http://dx.doi.org/10.1016/j.scitotenv.2014.02.020.

Liu, T., Wang, Q., \& Su, B. (2016). A review of carbon labeling: standards, implementation, and impact. Renewable \& Sustainable Energy Reviews, 53, 68-79. http://dx.doi.org/10.1016/j.rser.2015.08.050.

Mantyka-Pringle, C. S., Visconti, P., Di Marco, M., Martin, T. G., Rondinini, C., \& Rhodes, J. R. (2015). Climate change modifies risk of global biodiversity loss due to land-cover change. Biological Conservation, 187, 103-111. Retrieved from http://dx.doi.org/10.1016/j. biocon.2015.04.016

Meneses, M., Pasqualino, J., \& Castells, F. (2012). Environmental assessment of the milk life cycle: the effect of packaging selection and the variability of milk production data. Journal of Environmental Management, 107, 76-83. PMid:22591834. http://dx.doi.org/10.1016/j. jenvman.2012.04.019.

Muñoz, C., Hube, S., Morales, J. M., Yan, T., \& Ungerfeld, E. M. (2015). Effects of concentrate supplementation on enteric methane emissions and milk production of grazing dairy cows. Livestock Science, 175, 37-46. http://dx.doi.org/10.1016/j.livsci.2015.02.001.

National Development and Reform Commission - NDRC. (2014). China regional power grid emission factor report. Dublin: NDRC. Retrieved from http://qhs.ndrc.gov.cn/qjfzjz/200907/t20090703_289357.html

Nigri, E. M., Barros, A. C. D., Rocha, S. D. F., \& Romeiro Filho, E. (2014). Assessing environmental impacts using a comparative LCA of industrial and artisanal production processes:" Minas Cheese" case. Food Science and Technology (Campinas.), 34(3), 522-531. http://dx.doi.org/10.1590/1678-457x.6356. 
Noronha, C., Tou, S., Cynthia, M. I., \& Guan, J. J. (2013). Corporate social responsibility reporting in China: an overview and comparison with major trends. Corporate Social Responsibility and Environmental Management, 20(1), 29-42. http://dx.doi.org/10.1002/csr.1276.

Park, Y. S., Egilmez, G., \& Kucukvar, M. (2016). Emergy and endpoint impact assessment of agricultural and food production in the United States: a supply chain-linked ecologically-based life cycle assessment. Ecological Indicators, 62, 117-137. http://dx.doi. org/10.1016/j.ecolind.2015.11.045.

Riera, F. A., Suárez, A., \& Muro, C. (2013). Nanofiltration of UHT flash cooler condensates from a dairy factory: Characterisation and water reuse potential. Desalination, 309, 52-63. http://dx.doi. org/10.1016/j.desal.2012.09.016.

Rotz, C. A., Montes, F., \& Chianese, D. S. (2010). The carbon footprint of dairy production systems through partial life cycle assessment. Journal of Dairy Science, 93(3), 1266-1282. PMid:20172247. http:// dx.doi.org/10.3168/jds.2009-2162.

Rowlings, D. W., Grace, P. R., Scheer, C., \& Kiese, R. (2013). Influence of nitrogen fertiliser application and timing on greenhouse gas emissions from a lychee (Litchi chinensis) orchard in humid subtropical Australia. Agriculture, Ecosystems \& Environment, 179, 168-178. http://dx.doi.org/10.1016/j.agee.2013.08.013.

Seppälä, J. (2003). Life cycle impact assessment based on decision analysis (Ph.D. dissertation). Helsinki University of Technology, Espoo.

Thomassen, M. A., van Calker, K. J., Smits, M. C., Iepema, G. L., \& de Boer, I. J. (2008). Life cycle assessment of conventional and organic milk production in the Netherlands. Agricultural Systems, 96(1), 95-107. http://dx.doi.org/10.1016/j.agsy.2007.06.001.

Van-Middelaar, C. E., Berentsen, P. B. M., Dijkstra, J., \& De Boer, I. J. M. (2013). Evaluation of a feeding strategy to reduce greenhouse gas emissions from dairy farming: the level of analysis matters. Agricultural Systems, 121, 9-22. http://dx.doi.org/10.1016/j.agsy.2013.05.009.

Vergé, X. P. C., Maxime, D., Dyer, J. A., Desjardins, R. L., Arcand, Y., \& Vanderzaag, A. (2013). Carbon footprint of Canadian dairy products: calculations and issues. Journal of Dairy Science, 96(9), 6091-6104. PMid:23831091. http://dx.doi.org/10.3168/jds.2013-6563.
Wang, X., Kristensen, T., Mogensen, L., Knudsen, M. T., \& Wang, X. (2016). Greenhouse gas emissions and land use from confinement dairy farms in the Guanzhong plain of China-using a life cycle assessment approach. Journal of Cleaner Production, 113, 577-586. http://dx.doi.org/10.1016/j.jclepro.2015.11.099.

Woon, K. S., \& Lo, I. M. (2013). Greenhouse gas accounting of the proposed landfill extension and advanced incineration facility for municipal solid waste management in Hong Kong. The Science of the Total Environment, 458, 499-507. PMid:23697849. http://dx.doi. org/10.1016/j.scitotenv.2013.04.061.

World Resources Institute - WRI. (2004). The Greenhouse gas protocol: a corporate accounting and reporting standard. Washington, D.C.: WRI. Retrieved from http://www.wri.org/publication/greenhousegas-protocol

Xie, M., Li, L., Qiao, Q., Sun, Q., \& Sun, T. (2011). A comparative study on milk packaging using life cycle assessment: from PA-PE-Al laminate and polyethylene in China. Journal of Cleaner Production, 19(17), 2100-2106. http://dx.doi.org/10.1016/j.jclepro.2011.06.022.

Zhao, R., Deutz, P., Neighbour, G., \& McGuire, M. (2012). Carbon emissions intensity ratio: an indicator for an improved carbon labelling scheme. Environmental Research Letters, 7(1), 014014. http://dx.doi.org/10.1088/1748-9326/7/1/014014.

Zhao, R., Liu, Y., Zhang, N., \& Huang, T. (2017). An optimization model for green supply chain management by using a big data analytic approach. Journal of Cleaner Production, 142, 1085-1097. http:// dx.doi.org/10.1016/j.jclepro.2016.03.006.

Zhao, R., Neighbour, G., McGuire, M., \& Deutz, P. (2013). A software based simulation for cleaner production: a game between manufacturers and government. Journal of Loss Prevention in the Process Industries, 26(1), 59-67. http://dx.doi.org/10.1016/j.jlp.2012.09.006.

Zhao, R., Zhou, X., Han, J., \& Liu, C. (2016). For the sustainable performance of the carbon reduction labeling policies under an evolutionary game simulation. Technological Forecasting and Social Change, 112, 262-274. http://dx.doi.org/10.1016/j.techfore.2016.03.008. 